\title{
ANALISIS KESALAHAN BERBAHASA DALAM TATARAN SINTAKSIS PADA PIDATO SISWA KELAS XI SMA NEGERI 1 TIGANDERKET TAHUN PEMBELAJARAN \\ 2016/2017
}

Oleh

Perlinda Br Bangun (perlinda.bangun94@gmail.com)

Dr. Malan Lubis, M.Hum.

Penelitian ini bertujuan untuk mendeskripsikan bentuk kesalahan sintaksis yang meliputi: (1) kesalahan penggunaan struktur frasa pada Pidato kelas XI SMA Negeri 1 Tiganderket, (2) kesalahan penggunaan struktur kalimat pada Pidato kelas XI SMA Negeri 1 Tiganderket. Subjek penelitian ini adalah pidato siswa kelas XI SMA Negeri 1 Tiganderket Tahun Pembelajaran 2016/ 2017. Objek penelitian ini adalah frasa dan kalimat.Penelitian ini merupakan penelitian deskriptif kualitatif. Instrumen dalam penelitian ini adalah peneliti sendiri (Human instrumen), yaitu sebagai instrumen kunci dengan bantuan instrumen pendukung yang berupa tabel data. Penelitian ini juga menggunakan kriteria-kriteria sebagai perangkat lunak untuk memudahakan dalam pengambilan data dan analisis data. Kriteriakriteria yang digunakan adalah kriteria untuk menentukan kesalahan penggunaan frasa dan kesalahan penggunaan kalimat. Hasil pembahasan menunjukkan Jumlah keseluruhan kalimat yang mengandung kesalahan sintaksis dari 38 pidato yaitu 221 kesalahan dengan perincian $58,15 \%$, kesalahan dalam bentuk frasa $127(57,46$ $\%)$ kesalahan dalam bentuk kalimat 94 (42,53\%).

Kata Kunci: Frasa, Kalimat.

\section{PENDAHULUAN}

Manusia merupakan makhluk sosial, yakni makhluk yang memiliki kecenderungan untuk berinteraksi sosial dengan sesama. Berinteraksi sosial berarti manusia harus saling berkomunikasi, sebab dengan adanya komunikasi manusia dapat menyampaikan maksud atau pesan kepada orang lain, demikian sebaliknya. Agar satu sama lainnya dapat berkomunikasi dengan baik maka diperlukan keterampilan berbahasa yang baik pula. 
Bila melihat kurikulum tahun 2006 pada mata pelajaran Bahasa Indonesia kelas XI SMA, maka materi keterampilan berbahasa terbagi atas empat bagian yaitu keterampilan menyimak, berbicara, membaca dan menulis. Dari keempat keterampilan berbahasa tersebut yang menarik untuk dikaji adalah keterampilan berbicara.

Kesalahan bahasa pada dasarnya disebabkan pada diri orang yang menggunakan bahasa yang bersangkutan bukan pada bahasa yang digunakannya. Ada tiga kemungkinan penyebab seseorang dapat salah dalam berbahasa, antara lain: (a) terpengaruh bahasa yang lebih dahulu dikuasainya, (b) kekurangpahaman pemakai bahasa terhadap bahasa yang dipakainya, (c) pengajaran bahasa yang kurang tepat atau sempurna (Setyawati, 2010: 15-16).

Analisis kesalahan merupakan proses yang didasarkan pada analisis kesalahan orang yang sedang belajar dengan objek (yaitu bahasa) yang sudah ditargetkan. Bahasa yang ditargetkan dapat berupa bahasa ibu maupun bahasa nasional dan bahasa asing. Dalam penelitian ini targetnya adalah bahasa nasional.

Analisis kesalahan dapat berguna sebagai alat pada awal-awal dan selama tingkattingkat variasi program pengajaran target dilaksanakan.

Tindakan ini pada awalnya sebagai alat yang dapat membuka pikiran guru untuk mengatasi kerumitan bidang sintaksis yang dihadapkan pada murid. Seperti yang diungkapkan oleh Hastuti (2003: 78) bahwa jumlah frekuensi kesalahan dapat sangat membantu penemuan linguistik kontrastif. Penemuan ini dapat sangat membantu mengatur materi pengajaran dan melaksanakan pengajarannya.

Selain itu, beberapa penelitian yang pernah dilakukan menunjukkan bahwa pemahaman dan penguasaan struktur bahasa khususnya pemilihan kata (diksi), frasa, klausa, dan kalimat dalam bahasa lisan siswa masih rendah. Menurut hasil penelitian Musrifah (1999), kesalahan sintaksis masih sering terjadi pada penyusunan diksi, frasa, preposisi dan konjungsi. Begitu pula hasil penelitian 
Mardawaningsih (1999) yang menunjukkan bahwa siswa sering melakukan kesalahan dalam pemilihan dan penyusunan diksi.

Sebelumnya peneliti juga telah melakukan wawancara dengan salah satu guru Bahasa Indonesia di SMA Negeri 1 Tiganderket, Yang bernama Bapak Drs. Erwin Tanjung. menyatakan bahwa masih banyak siswa yang melakukan kesalahan berbahasa. Termasuk juga pemahaman dan penguasaan struktur Frasa dan Kalimat. Hal ini disebabkan karena siswa/siswi masih terpengaruh dengan bahasa Ibu/bahasa pertama mereka.

Berdasarkan uraian di atas, dapat disimpulkan bahwa yang perlu diteliti dalam analisis kesalahan sintaksis adalah penyimpangan pada penyusunan atau frasa, dan kalimat. Kesalahan atau penyimpangan sintaksis yang dilakukan siswa terjadi akibat kekurangpahaman siswa terhadap kaidah tata bahasa yang digunakan atau mungkin faktor lain seperti kekhilafan atau kecerobohan yang dilakukan siswa. Dan Peneliti tertarik untuk mengetahui dan mempelajari lebih dalam jenis penyimpangan atau kesalahan sintaksis yang dilakukan oleh siswa. Adapun yang menjadi subjek penelitian ini adalah hasil berpidato siswa kelas XI SMA Negeri 1 Tiganderket Tahun ajaran 2016/2017.

\section{METODE PENELITIAN}

Metode penelitian yang peneliti gunakan pada penelitian ini adalah metode deskriptif kualitatif, seperti yang dijelaskan oleh Bogdan dan Taylor, dalam Moelong (2006) mendefenisikan bahwa " metodologi kualitatif sebagai prosedur penelitian yang menghasilkan data deskriptif berupa kata-kata tertulis atau lisan dari orang-orang dan perilaku yang menyajikan data deskriptif mengenai kesalahan sintaksis pada pidato siswa kelas XI SMA Negeri 1 Tiganderket.

Peneliti berusaha mendeskripsikan data-data yang telah peneliti peroleh melalui pengumpulan data. Teknik pengumpulan data dilakukan dengan cara mempersiapkan instrumen penelitian berupa alat rekaman langsung (handphone) guna memperoleh data tentang kemampuan penggunaan kontruksi sintaksis yang 
berupa frasa dan kalimat pada pidato siswa dan mempersiapkan lembaran namanama siswa yang ditunjuk untuk berpidato di depan kelas.

\section{HASIL PENELITIAN DAN PEMBAHASAN}

\section{Kesalahan Penggunaan Struktur Frasa}

\section{a. Penggunaan Preposisi yang Tidak Tepat}

(1) Puji dan syukur kita ucapkan ke Tuhan Yang Maha Esa.( $\left.\mathrm{P}_{7 \text { pembuka }}\right)$

Kata-kata yang dicetak miring kalimat di atas merupakan penggunaan preposisi yang tidak tepat. Pada kalimat (1) lebih tepat preposisi ke dihilangkan karena dalam konteks itu preposisi ke hanya menyatakan tempat, Pada kalimat

Perbaikan kalimat di atas adalah sebagai berikut.

(1a) Puji dan syukur kita ucapkan kepada Tuhan Yang Maha Esa.( $\mathrm{P}_{7}$ pembuka)

\section{b. Susunan Kata yang tidak Tepat}

(2) Disini berdiri saya untuk menyampaikan pidato tentang kebersihan. (P 11 isi)

Susunan kata-kata yang dicetak miring pada kalimat (2) tidak sesuai kaidah bahasa Indonesia.

(2a) saya berdiri disini untuk menyampaikan pidato tentang kebersihan. ( $\mathrm{P}$ 11 isi)

\section{c. Penggunaan Unsur yang Berlebihan atau Mubazir}

Pada Pidato Siswa Kelas XI SMA Negeri 1 Tiganderket dijumpai pemakaian kata-kata yang mengandung makna yang sama (bersinonim) digunakan sekaligus dalam sebuah kalimat. Perhatikan beberapa kalimat berikut.

(3) Dampak buruk negatif dari membuang sampah sembarangan. $\left(\mathrm{P}_{14}\right.$ isi $)$ 
Penggunaan dua kata yang bersinonim sekaligus dalam sebuah kalimat dianggap mubazir karena tidak hemat.

(3a) Dampak buruk dari membuang sampah sembarangan. $\left(\mathrm{P}_{14}\right.$ isi $)$

\section{d. Penjamakan yang Ganda}

(4) Para hadirin-hadirin yang terhormat, kita tahu bahwa pendidikan itu sangat penting. $\left(\mathrm{P}_{1 \text { pembuka }}\right)$

Dalam sebuah kalimat untuk penanda jamak sebuah kata cukup menggunakan satu penanda saja; jika sudah terdapat penanda jamak tidak perlu kata tersebut diulang atau jika sudah diulang tidak perlu menggunakan penanda jamak. Sebaiknya kalimat (4) diungkapkan menjadi kalimat berikut ini.

(4a) Para hadirin yang terhormat, kita tahu bahwa pendidikan itu sangat penting. $\left(\mathrm{P}_{1 \text { pembuka }}\right)$

(4b) Hadirin yang terhormat, kita tahu bahwa pendidikan itu sangat penting. $\left(\mathrm{P}_{1 \text { pembuka }}\right)$

\section{e. Penggunaan bentuk Superlatif yang berlebihan}

Bentuk superlatif adalah suatu bentuk yang mengandung arti 'paling' dalam suatu perbandingan. Bentuk yang mengandung arti 'paling' itu dapat dihasilkan dengan suatu adjektiva ditambah adverbia amat, sangat, sekali, atau paling. Jika ada dua adverbia digunakan sekaligus dalam menjelaskan adjektiva pada sebuah kalimat, terjadilah superlatif yang berlebihan seperti kalimat berikut.

(6) Sukses itu sangatlah enak, enak sekali khususnya untuk pria.( $\left.\mathrm{P}_{1 \text { isi }}\right)$

Kita harus membiasakan memakai kalimat-kalimat seperti di bawah ini Untuk memperbaiki kalimat-kalimat di atas.

(6a) Sukses itu sangat enak khususnya untuk pria. $\left(\mathrm{P}_{1 \text { isi }}\right)$ 


\section{f. Penggunaan bentuk resiprokal yang salah}

Bentuk resiprokal adalah bentuk bahasa yang mengandung arti 'berbalasan'. Bentuk resiprokal dapat dihasilkan dengan cara menggunakan kata saling atau dengan kata ulang berimbuhan. Akan tetapi, jika ada bentuk yang berarti 'berbalasan' itu dengan cara pengulangan kata sekaligus dengan menggunakan kata saling, akan terjadilah bentuk resiprokal yang salah seperti kalimat berikut ini.

(7) Kalian saling tolong-menolong dalam kegiatan ini.( $\left.\mathrm{P}_{11 \text { isi }}\right)$

Bentuk resiprokal yang sudah disebutkan diatas dapat diperbaiki menjadi bentuk-bentuk berikut.

(7a) Kalian tolong-menolong dalam kegiatan ini. $\left(\begin{array}{ll}\mathrm{P}_{11} & \text { isi }\end{array}\right)$

(7b) Kalian saling menolong dalam kegiatan ini. $\left(\mathrm{P}_{11}\right.$ isi $)$

\section{Kesalahan Penggunaan Struktur Kalimat}

\section{a. Kalimat tidak bersubjek}

Kalimat itu paling sedikit harus terdiri atas subjek dan predikat, kecuali kalimat perintah atau ujaran yang merupakan jawaban pertanyaan. Biasanya kalimat yang subjeknya tidak jelas terdapat dalam kalimat rancu, yaitu kalimat yang berpredikat verba aktif transitif di depan subjek terdapat preposisi. Misalnya

(8) untuk kegiatan menanam pohon itu memerlukan biaya yang cukup banyak. $\left(\mathrm{P}_{34}\right.$ isi $)$

Perbaikan kalimat di atas dapat dilakukan dengan dua cara, yaitu (a) jika ingin mempertahankan preposisi yang mendahului subjek, maka predikat diubah menjadi bentuk pasif dan (b) jika menghendaki predikat tetap dalam bentuk aktif, maka preposisi yang mendahului subjek harus dihilangkan.

(8a) untuk kegiatan menanam pohonitu diperlukan biaya yang cukup banyak. $\left(\mathrm{P}_{34}\right.$ isi $)$ 
(8b) Kegiatan menanam pohon itu memerlukan biaya yang cukup banyak. $\left(\mathrm{P}_{34}\right.$ isi $)$

\section{b. Antara Predikat Dan Objek Tersisipi}

(9) Kami mengharapkan atas kehadiran saudara tepat pada waktunya. $\left(\mathrm{P}_{19}\right.$ isi $)$

Dalam kalimat aktif transitif, yaitu kalimat yang memiliki objek; verba transitif tidak perlu diikuti oleh preposisi sebagai objek. Dengan kata lain, antara predikat dan objek tidak perlu disisipi preposisi,seperti akan, tentang, dan atas.

(9a) Kami mengharapkan kehadiran saudara tepat pada waktunya.

\section{c. Kalimat Yang Tidak Logis}

Yang dimaksud dengan kalimat tidak logis adalah kalimat yang tidak masuk akal. Hal ini terjadi karena pembicara atau penulis kurang berhati-hati dalam memilih kata.

(10) Untuk mempersingkat waktu.( $\left.\mathrm{P}_{11 \text { pembuka }}\right)$

Ketidaklogisan terdapat pada makna kata mempersingkat waktu. Kata mempersingkat waktu makna leksikalnya sama dengan 'memperpendek'. Jadi, tidak mungkin kalau waktu sampai diperpendek karena waktu itu tidak mungkin dipersingkat atau diperpendek, sehari semalam tetap 24 jam. Kata yang tepat untuk menyatakan maksud tersebut adalah kata menghemat. (10a) Untuk menghemat waktu.( $\left.\mathrm{P}_{11 \text { pembuka }}\right)$

\section{d. Penghilangan Konjungsi}

Di dalam Pidato siswa kelas XI SMA Negeri 1 Tiganderket terdapat gejala penghilangan konjungsi pada anak kalimat. Justru penghilangan konjungsi itu menjadikan kalimat tersebut tidak efektif (tidak baku). Perhatikan contoh-contoh kalimat berikut ini.

(11) saya berharap kepada masyarakat desa ini saling tolong menolong membersihkan sampah yang ada di sungai. $\left(\mathrm{P}_{14}\right.$ isi $)$ 
Dalam bahasa Indonesia, konjungsi pada anak kalimat harus digunakan sehingga kalimat-kalimat di atas dapat diperbaiki menjadi kalimat berikut ini.

(11a) saya berharap kepada masyarakat desa ini supaya saling tolong menolong membersihkan sampah yang ada di sungai. $\left(\mathrm{P}_{14}\right.$ isi $)$

\section{e. Penggunaan Konjungsi yang berlebihan}

(12) dan saya berdiri disini untuk menjelaskan tentang pendidikan. $\left(\mathrm{P}_{1 \text { pembuka }}\right)$

Siswa kelas XI SMA Negeri 1 Tiganderket tidak menyadari kalau bentukbentuk kalimat di atas menggunakan padanan yang tidak serasi, yaitu penggunaan dua konjungsi sekaligus. Seharusnya konjungsi yang digunakan salah satu saja. Perbaikan kalimat-kalimat tersebut dapat dituliskan sebagai berikut.

(12a) ... saya berdiri disini untuk menjelaskan tentang pendidikan.( $\left.\mathrm{P}_{1 \text { pembuka }}\right)$

\section{f. Penggunaan Kata Tanya Yang Tidak Perlu}

Dalam bahasa Indonesia sering dijumpai penggunaan bentuk kata tanya yang tidak perlu, seperti di mana, yang mana, hal mana, dari mana dan kata-kata tanya yang lain sebagai penghubung atau terdapat dalam kalimat berita ( bukan kalimat tanya).

(13) di mana pada siang hari ini kita dapat berkumpul bersama. $\left(\mathrm{P}_{1 \text { pembuka }}\right)$

Penggunaan bentuk-bentuk tersebut kemungkinan besar dipengaruhi oleh bahasa asing, khususnya bahasa inggris. Bentuk yang mana sejajar dengan penggunaan which penggunaan dalam mana sejajar dengan di mana (in which). Dalam bahasa Indonesia sudah ada penghubung yang lebih tepat, yaitu kata tempat dan yang, perbaikan kalimat(13).

(13a) Pada siang hari ini kita dapat berkumpul bersama.( $\left.\mathrm{P}_{1 \text { pembuka }}\right)$ 


\section{g. Istilah Asing.}

(14) Zaman yang cool. $\left(\mathrm{P}_{1 \text { isi }}\right)$

Kalimat-kalimat tersebut terdapat istilah asing. Akan lain halnya jika istilah asing yang dicetak miring pada masing-masing kalimat di atas diganti dengan istilah dalam bahasa Indonesia, istilah cool diganti dengan keren (canggih), (14a) Zaman yang canggih. $\left(\mathrm{P}_{1 \text { isi }}\right)$

\section{PEMBAHASAN HASIL PENELITIAN}

Pembahasan dalam penelitian ini meliputi kesalahan sintaksis yang berupa frasa dan kalimat dalam Pidato Siswa Kelas XI SMA Negeri 1 Tiganderket. Adapun pembahasan hasil penelitian tersebut adalah sebagai berikut.

1. Kesalahan penggunaan struktur Frasa

Pada pidato siswa kelas XI SMA Negeri 1 Tiganderket ditemukan 127 kalimat atau dengan perincian 57,46\% dari jumlah keseluruhan kalimat kesalahan sintaksis. Pada penelitian ini siswa banyak mengalami kesalahan penggunaan sintaksis berupa frasa pada pidato siswa. Penggunaan unsur yang berlebihan atau mubazir adalah kesalahan penggunaan sintaksis berupa Frasa terbanyak, hal ini disebabkan penggunaan unsur tidak dikuasai sisa dalam berpidato. Pengguasaan penggunaan unsur sesuai kaidah bahasa Indonesia sudah diajarkan dalam proses pembelajaran oleh guru, namun siswa tidak mampu menguasai kaidah bahasa Indonesia tersebut karena ketidakbiasaan siswa dalam menggunaakan bahasa Indonesia. Tugas yang diberikan kepada siswa mengenai pidato di depan kelas telah terlaksana, tetapi guru mata pelajaran tidak memiliki perhatian khusus mengenai penilaian kesalahan berbahasa dalam tataran sintaksis. Siswa yang tidak menerima penilaian mengenai kesalahan sintaksis tersebut, siswa merasa bahwa ia sudah mampu menuliskan pidato serta berpidato di depan kelas. Dengan demikian siswa tidak teliti dan berhati-hati dalam menggunakan Bahasa Indonesia. Kesalahan penggunaan struktur kalimat. 
Dalam pidato siswa tersebut ditemukan sebanyak 94 kalimat dengan perincian $42,53 \%$ dari jumlah keseluruhan kesalahan sintaksis.

Penggunaan struktur kalimat terkhususnya kalimat tidak logis dikarenakan ketidaktelitian siswa dalam berbicara/ pidato. Ketidaktelitian ini terjadi akibat siswa tidak terbiasa menggunakan bahasa Indonesia dan siswa lebih mengutamakan bahasa pertamanya (Karo).

Kesalahan penggunaan sintaksis berupa kalimat disebabkan kekurangpahaman siswa terhadap bahasa Indonesia. Penerapan kaidah yang tidak sempurna dapat dilihat dari hasil penelitian terdapatnya kesalahan sintaksis berupa kalimat. Siswa mendapat pengajaran bahasa Indonesia yang kurang sempurna. Hal ini terjadi berkaitan dengan bahan yang diajarkan atau yang dilatihkan dalam pelaksanaan pengajaran belum maksimal menerapkan kaidah bahasa Indonesia.

Berdasarkan penelitian ini dapat dilihat bahwa siswa masih minim pemahaman penggunaan sintaksis dalam berpidato. Siswa cukup pandai dalam mengargumentasikan pendapatnya pada tulisan.

\section{PENUTUP}

Berdasarkan hasil temuan data dan pembahasan dapat ditarik kesimpulan mengenai Analisis Kesalahan Berbahasa dalam Tataran Sintaksis pada Pidato Siswa Kelas XI SMA Negeri 1 Tiganderket Tahun Pembelajaran 2016/2017 dapat disimpulkan sebagai berikut.

1. Kesalahan penggunaan sintaksis berupa frasa pada Pidato Siswa Kelas XI SMA Negeri 1 Tiganderket sebanyak 127 kalimat dengan perincian 57,46\%, kesalahan penggunaan Frasa tersebut meliputi : Penggunaan preposisi yang tidak tepat, Susunan kata yang tidak tepat, Penggunaan unsur yang berlebihan/mubazir, Penjamakan yang ganda, Penggunaan bentuk superlatif yang berlebihan, Penggunaan bentuk Resiprokal yang salah. 
2. Kesalahan penggunaan sintaksis berupa kalimat pada Pidato siswa kelas XI SMA Negeri 1 Tiganderket sebanyak 94 kalimat dengan perincian 42, 53\% kesalahan penggunaan kalimat tersebut meliputi : kalimat yang tidak bersubjek, antara predikat dan objek tersisipi, kalimat yang tidak logis, penghilangan konjungsi, penggunaan konjungsi yang berlebihan, penggunaan kata tanya yang tidak perlu, istilah asing.

\section{DAFTAR PUSTAKA}

Hastuti, Sri. 2003. Sekitar Analisis Kesalahan berbahasa Indonesia. Yogyakarta: PT Mitra Gama.

Istinganah, Nurul. 2012. Analisis Kesalahan Sintaksis Pada Karangan Narasi Ekspositoris Siswa Kelas VIII SMP Negeri 1 Banguntapan,Bantul,Yogyakarta. Yogyakarta: Universitas Negeri Yogyakarta.

Mardawaningsih, Dwi. 1999. Analisis kesalahan kosakata dan ketidakefektifan kalimat padakarangan siswa kelas II SLTP Negeri 1 Playen Gunung Kidul Yogyakart. Yogyakarta: IKIP Yogyakarta.

Moleong, L.J. (2006). Metodelogi Penelitian Kualitatif. PT. Remaja Rosdakarya.

Setyawati, Nanik. 2010. Analisis Kesalahan Berbahasa. Surakarta: Yuma Pustaka. 